\title{
Do plant species of different resource qualities form dissimilar energy channels below-ground?
}

\section{Witt, Christina}

2010

Witt , C \& Setala , H 2010 , ' Do plant species of different resource qualities form dissimilar energy channels below-ground? ' , Applied Soil Ecology , vol. 44 , no. 3 , pp. 270-278 . https://doi.org/10.1016/j.apso

http://hdl.handle.net/10138/24361

https://doi.org/10.1016/j.apsoil.2010.01.004

publishedVersion

Downloaded from Helda, University of Helsinki institutional repository.

This is an electronic reprint of the original article.

This reprint may differ from the original in pagination and typographic detail.

Please cite the original version. 


\title{
Do plant species of different resource qualities form dissimilar energy channels below-ground?
}

\author{
Christina Witt* , Heikki Setälä \\ Department of Environmental Sciences, University of Helsinki, Niemenkatu 73, 15140 Lahti, Finland
}

\section{A R T I C L E I N F O}

\section{Article history:}

Received 6 July 2009

Received in revised form 9 January 2010

Accepted 14 January 2010

\section{Keywords:}

Soil decomposer community

Plant-soil feedback

Bacterial-based

Fungal-based

Root channel

Energy channels

Nutrient retention

\begin{abstract}
A B S T R A C T
This study aimed at examining whether plant species of varying resource quality give rise to a fungal- or bacterial-based energy channel in the plants' rhizosphere, when planted in soil, in which the plant species naturally occur. In an 18-month large-scale laboratory mesocosm experiment, two plant species (Holcus lanatus and Lotus corniculatus) producing labile litter and two plant species (Picea abies and Calluna vulgaris) producing recalcitrant litter were placed in the same mesocosm. This allowed the decomposer biota (microbes, protozoa, nematodes, collembolans, and enchytraeid worms) to freely choose their preferred plant rhizosphere. Because a fungal-based energy channel is in theory regarded to retain nutrients better in the soil than a bacterial-based energy channel, water was collected underneath the plant species and analyzed for its nutrient ( $\mathrm{N}$ and $\mathrm{P}$ ) content.

In general, the number of soil biota groups responding significantly to the plant treatment increased with time. Soil microbes were the first group to react, but the ability of the plants to boost a clearly fungal- or bacterial-based energy channel was generally weak. However, at the end of the study, a higher fungal-to-bacterial biomass ratio was found beneath Calluna than beneath the other plant treatments. Of the secondary consumers, nematodes were the most responsive group, with total number and especially plant parasites being more abundant beneath Lotus than beneath Picea and Calluna indicating a rootbased energy channel to persist under the legume. Protozoa, enchytraeid worms and collembolans responded weakly and inconsistently to plant treatment. Liberation of plant-available nutrients was plant-dependent. Towards the end of the study, less nitrate and phosphate leached through the Picea soils than through the control, which indicates a more effective nutrient retention to take place under this plant species. We found that plant species can, in a relatively short time, modify the composition of the soil decomposer community. However, no consistent evidence for the plant-soil systems developing to separated detritus energy channels emerged, we found a clearly separated root energy channel under the legume $L$. corniculatus.
\end{abstract}

(c) 2010 Elsevier B.V. All rights reserved.

\section{Introduction}

Primary producers, particularly vascular plants, are known to evolve reciprocal, mutualistic relationships with decomposer communities in the soil (Wardle, 2002). While activities of soil biota regulate plant growth (Bonkowski et al., 2000; Bever, 2003; Wardle et al., 2004), plants affect the soil and its organisms through, for instance, the uptake of water and nutrients. Evidence indicates, that plants influence the composition of the soil decomposer community through variation in the quantity and quality of litter (Wardle et al., 2006) and root exudates (Bais et al., 2006). Moore and Hunt (1988) proposed that the degradation of plant-derived material depends on the chemical nature of the

\footnotetext{
* Corresponding author. Tel.: +3589 1912 0332; fax: +3589 19120331.

E-mail address: christina.witt@helsinki.fi (C. Witt).
}

resources (recalcitrant or labile), and that the decomposition (i.e. detritus channel, Moore and Hunt, 1988) is divided into two separate energy/nutrient channels: a bacterial-based channel and a fungal-based channel. A separate energy channel is characterized by living plant roots (i.e. the root channel).

Plant species identity seems to play a role in this (Wardle and Nicholson, 1996; Priha and Smolander, 1997; Bardgett et al., 1999a,b; de Deyn et al., 2004; Wardle, 2005). Slow-growing plants, such as conifers or hardy dwarf shrubs, produce poor-quality (recalcitrant) litters due to their high $\mathrm{C}: \mathrm{N}$ ratio, high lignin content, and the presence of large amounts of phenolic compounds (Priha and Smolander, 1997; Wardle, 2002), slowing down the decomposition of such litters. Furthermore, secretion of root-derived compounds (root exudation) by conifers is hampered due to the ectomycorrhizal hyphal mantle around their roots. This can lead not only to reduced growth of bacteria (Olsson et al., 1996), but also of their predators, such as protozoa (Timonen et al., 2004). 
In contrast, fast-growing plants, such as grasses and herbs, produce labile, easily decomposable litter (Priha and Smolander, 1997; Bardgett, 2005). These plant species commonly exude plenty of resources to the soil through root exudation. The energy channel theory of Moore and Hunt (1988) predicts that plants producing recalcitrant resources and liberating reduced amounts of root exudates promote a fungal-based energy channel underneath, which is characterized by a higher amount of fungal than bacterial biomass. A decomposer food web with a relatively higher bacterial than fungal biomass is likely to exist beneath plant species that produce labile litters. The energy channel theory rests on the assumption that, of the two primary decomposer groups bacteria and fungi, only fungi are able to degrade recalcitrant resources efficiently (de Boer et al., 2005). Given that the consumers of fungi and bacteria differ in their diet, for example Collembola are regarded commonly as fungal feeders (Hopkin, 1997) while protozoa as bacterial consumers (Bonkowski et al., 2000), a cascading effect is expected to take place higher up in the soil food web. Consequently, more fungal feeding nematodes and microarthropods are anticipated to settle beneath plant species that produce recalcitrant material, whereas beneath labile plant species a food web rich in bacterivores is expected. According to Moore and Hunt (1988) the root channel is characterized by a high number of root feeding nematodes, followed by predatory nematodes and nematophagous mites.

The influence of different plant species or species communities on soil decomposers has been studied in various terrestrial ecosystems. For example, soil microbial biomass (Wardle and Nicholson, 1996; Priha et al., 2001; Innes et al., 2004), and its composition (Bardgett and McAlister, 1999; Priha et al., 2001) and activity (Bradley and Fyles, 1995) have been shown to vary beneath different plant species. Knapp et al. (2009) recently showed that different food recourses also influence the microflora through the gut microbes of earthworms. Furthermore, changes in plant species or species properties have been proven to affect the composition of soil microfauna (protozoa: Timonen et al., 2004; nematodes: Ingham et al., 1985; de Deyn et al., 2004; Saj et al., 2007) and of mesofauna (microarthropods: Petersen and Luxton, 1982).

Plant community composition can reflect the rate at which nutrients are cycled within a system and hence affect the fertility of the soil (Mulder et al., 2002; Bever, 2003). The fungal-based energy channel is assumed to be more conservative, being capable of retaining nutrients in the system better than a strongly bacterial-dominating system (Coleman et al., 1983; Wardle et al., 2004; van der Heijden et al., 2008). Recently de Vries et al. (2006) and Gordon et al. (2008) showed that fungaldominated systems tend to loose less nitrogen by leaching than bacterial-dominated systems.

Despite the existence of distinct fungal-dominating (such as coniferous forests) and bacterial-dominating (such as grasslands) plant communities, we know little how responsive the various trophic levels of the below-ground decomposer community are to variation in single plant species or different plant community compositions (Wardle and Nicholson, 1996; Bardgett and Shine, 1999; Wardle et al., 2003; Wardle, 2005). In order to find out whether plant species have the ability to control the composition of decomposer community, we designed our experiment to test the following hypotheses:

(i) the perennial grass Holcus lanatus and the legume Lotus corniculatus promote a bacterial-dominating system beneath, while the dwarf shrub Calluna vulgaris and the coniferous tree Picea abies promote a fungal-dominating soil food web;

(ii) the divergent energy channels give rise to dissimilar higher level decomposer communities; (iii) nutrients ( $\mathrm{N}$ and $\mathrm{P}$ ) leach out in higher amounts from soil beneath Lotus and Holcus and from the plant-free soil than from soil beneath Calluna and Picea.

To test these hypotheses, we used a novel laboratory experimental approach that allowed soil biota to freely choose and establish in their favored below-ground environment during an 18-month (three growth periods for the plants) experiment.

\section{Methods}

\subsection{Mesocosms}

Eight round plastic vats ( $\varnothing 50 \mathrm{~cm}$, depth $40 \mathrm{~cm}$ ) were prepared as experimental mesocosms. Each was divided into five sections by a 5-cm-high plastic wall glued to the bottom of the mesocosms to form one circular section $(\varnothing 17 \mathrm{~cm})$ in the center, and four outer trapeze-shaped sectors of similar area. A lysimeter system to collect water leachates was adjusted to the bottom of each section. The lysimeters consisted of a plastic funnel $(\varnothing 5 \mathrm{~cm})$ glued upside down on a conventional garden root mat (mesh size $<0.5 \mathrm{~mm}$ ). The root mat efficiently prevented root growth and particle flow into the funnel, when the system was irrigated with water. The mesocosms were filled with $30 \mathrm{~kg}$ (fresh mass) of soil, forming a 12-cm-deep layer, i.e. reaching $7 \mathrm{~cm}$ above the rims of the plastic walls on the bottom. The soil was the common test soil applied in the multinational project BIORHIZ (Biotic Interactions in the Rhizosphere as structuring forces for plant communities). It was collected in February 2005 at a re-established grassland area next to the CLUE site in the Netherlands (Planken Wambius, Ede, $52^{\circ} 04^{\prime} \mathrm{N} 5^{\circ} 45^{\prime} \mathrm{E}$ ), where the last crop plant in 1995 was corn. The site is surrounded by heath, mixed forest, and abandoned arable land (van der Putten et al., 2000; Hedlund et al., 2003). The soil was transferred to Lahti, Finland, and stored at $4{ }^{\circ} \mathrm{C}$ in darkness until the experiment started. It had an organic carbon content of $21.3 \mathrm{~g} \mathrm{~kg}^{-1}$, a total $\mathrm{N}$ content of $1.27 \mathrm{~g} \mathrm{~kg}^{-1}$, a total P content of $0.33 \mathrm{~g} \mathrm{~kg}^{-1}$, and a $\mathrm{pH}$ (water) of 6.3. Stones, soil macrofauna, and plant debris were sorted out by hand, and the soil was homogenized by gently mixing.

\subsection{Plants and litter}

As model plants we selected the perennial grass $H$. lanatus, the legume L. corniculatus, the hardy shrub $C$. vulgaris and the conifer $P$. abies. Holcus and Lotus occur naturally in the site of the soils origin and were used as model plants in the above-mentioned project BIORHIZ. They are regarded to produce easy decomposable litter (Bardgett, 2005), whereas Calluna and Picea produce recalcitrant litter (Wardle, 2002). All plants differ in their root symbionts: Holcus: arbuscular mycorrhiza (West, 1996), Lotus: nitrogen fixing bacteria (Bardgett, 2005) and arbuscular mycorrhiza (Scheublin et al., 2004), Calluna: ericoid mycorrhiza (Genney et al., 2000), and Picea: ectomycorrhiza (Bonkowski et al., 2001).

Before initiation of the experiment, $10 \mathrm{~g}$ of fresh litter, collected at the site where the soil originated, was placed on the surface of each mesocosm to ensure an effective inoculation of the systems with soil biota. This method is not sufficient to inoculate the experiment with the entire soil biota. Hence euedaphic life forms are not considered in this study. The litter was removed 1 week after placement. Each outer sector of the mesocosms received one plant species either as seedlings or as seeds. P. abies seedlings (five 3-month-old seedlings for each mesocosm) were pre-grown in quartz sand and provided with Ingestad nutrient solution (Ingestad, 1979) every month. C. vulgaris (five 8-cm-high seedlings for each mesocosm, with debris attached to the roots carefully removed) was collected from a road bank in southern Finland. 
H. lanatus and L. corniculatus (Appel Gehölzsamen, Germany) were seeded ( 10 seeds per mesocosm). To ensure mycorrhization of the Picea seedlings, a small amount ( $0.5 \mathrm{~g}$ in dry mass) of fresh Picea roots collected from the field were cut into $1-\mathrm{cm}$ pieces and mixed with the Picea sector just before planting the seedlings. The circular core in the center remained as the plant-free control. To prevent roots from invading the other sectors, they were cut along the plastic section "borders" every 2 weeks with a sharp knife.

Each plant sector received an inoculum of dried (defaunated) litter of its own kind on the surface of the respective sector. This was to simulate natural conditions right from the start for the decomposer community and to ensure a maximal influence of the plant species plus their respective litter on the soil. The litter was taken from the field ( $P$. abies and $C$. vulgaris) or was separately pregrown (H. lanatus and L. corniculatus) in the experimental soil prior to the start of the experiment. The sectors growing Picea received $10 \mathrm{~g}$ of dried twigs and needles (1/1), those growing Calluna $7 \mathrm{~g}$ of dried twigs and leaves (1/1), those growing Holcus $1.5 \mathrm{~g}$ of dried leaves, and those growing Lotus $1 \mathrm{~g}$ of dried twigs and leaves (1/1). The amount of litter was chosen so as to form a layer that covers the soil and thereby helps in maintaining suitable abio-biotic conditions in the rhizospheres. The plants were provided with tap water every second day with a garden sprayer. Based on the varying water needs of the plant species, sectors with Lotus and Holcus received twice as much water than those with Picea or Calluna or the bare soil. Due to the extensive growth of Holcus and Lotus, their above-ground parts were cut after each growing season. To maintain the litter layer to mimic natural litter fall after growth periods and hence keep the natural conditions for the decomposer community and to prevent the soil from drying out, $50 \mathrm{~g}$ of Holcus litter and $100 \mathrm{~g}$ of Lotus litter were returned to the respective container sectors after the first sampling ( 5 months after the start of the experiment). Picea and Calluna sectors received dried and defaunated field-litter: $10 \mathrm{~g}$ of Picea and $5 \mathrm{~g}$ of Calluna litter after the first sampling, and $15 \mathrm{~g}$ of Picea and $10 \mathrm{~g}$ of Calluna after the second sampling.

\subsection{Experiment}

The experiment was conducted in a growth room. The mesocosms were placed in a water bath (depth $5 \mathrm{~cm}$ ) without direct contact to the water and with changing water temperature according to the season $\left(10{ }^{\circ} \mathrm{C}\right.$ summer, $8{ }^{\circ} \mathrm{C}$ autumn, and $5{ }^{\circ} \mathrm{C}$ winter). The experiment started with a 5-month summer period, with an average day temperature of $23^{\circ} \mathrm{C}$ and a night temperature of $15{ }^{\circ} \mathrm{C}$ (measured $10 \mathrm{~cm}$ above the soil surface). The light/dark cycle was $16 / 8 \mathrm{~h}$, with a photon flux density of $100 \mu \mathrm{mol} \mathrm{m}^{-2} \mathrm{~s}^{-1}$. After this, a 2-month autumn was established by decreasing stepwise the temperature to $15^{\circ} \mathrm{C}$ (day; $10 \mathrm{~h}$ ) and $10{ }^{\circ} \mathrm{C}$ (night; $14 \mathrm{~h}$ ), and illumination intensity was cut to half. During the 1month winter period a continuous darkness with a temperature of $8{ }^{\circ} \mathrm{C}$ was maintained. After the winter, the second period started with 1 -month spring with increasing temperature to $15 / 10{ }^{\circ} \mathrm{C}$ (day/night) and an average illumination intensity of $50 \mu \mathrm{mol} \mathrm{m} \mathrm{m}^{-2} \mathrm{~s}^{-1}$ was established. Spring was followed by 3month summer, 1 month autumn and 1-month winter. The third growth period consisted of 1-month spring, followed by 3-month summer, after which the experiment was samples the last time. All together this made the experiment last for 18 months.

\subsection{Sampling and analyses}

The experiment was sampled at the end of each summer period. At the first sampling, a single soil core $(\varnothing 9 \mathrm{~cm}$, depth $12 \mathrm{~cm})$ was randomly taken from the planted sectors and the plant-free section. The samples were then divided into subsamples for analyses of soil fauna, microbes, and soil abiotic characteristics (see below). At the second and third samplings, separate soil samples for each of the variables were taken. The holes resulting from the sampling procedure were filled with quartz sand to keep the structure and moisture of the adjacent soil as normal as possible. After each artificial summer, the position of the mesocosms in the growth room was randomized.

\subsection{Microbial community analyses}

\subsubsection{Basal and substrate-induced respiration}

Soil microbial biomass and activity were estimated from $100 \mathrm{~g}$ (samplings 1 and 2 ) or $10 \mathrm{~g}$ (sampling 3 ) of fresh soil samples. After removing plant parts, the soil was placed in respiration jars (closed $200 \mathrm{ml}$ containers with a hole in their lid, the hole was closed by a septum through which the air sample was taken), and the soil water content was adjusted to $20 \%$ of fresh mass. Basal respiration (microbial activity) in the soil was measured by taking a 1-ml air sample from the respiration jars ( 0 and $2 \mathrm{~h}$ after start) by syringe and analyzed for $\mathrm{CO}_{2}$ using an infrared carbon analyzer (samplings 1 and 2: EQ 90 Easy Quant Universal Carbon Analyzer; sampling 3: Apollo 9000 Combustion TOC Analyzer, Teledyne, Tekmar). Substrate-induced respiration (SIR), an indicator of microbial biomass, was measured by analyzing the $\mathrm{CO}_{2}$ evolution after 2 and $4 \mathrm{~h}$ from the same soil upon addition of glucose (powder, 2\% of fresh sample mass) (Beck et al., 1995).

\subsubsection{Phospholipid fatty acid analyses}

Differences in the microbial community were determined by analyzing the ester-linked phospholipid fatty acid (PLFA) composition of microbes extracted from soil samples, of which plant parts were removed. Extraction and the analysis procedure of PLFAs followed those described by Frostegård et al. (1991). Two replicate samples per mesocosms section $(=2 \times 5)$ were analyzed for each sampling. Briefly, lipids were extracted from $1.5 \mathrm{~g}$ of freeze-dried soil by shaking in a one-phase mixture of chloroform, methanol, and citrate acid buffer $(1: 2: 0.8, \mathrm{v} / \mathrm{v} / \mathrm{v})$ overnight. After centrifugation (2500 rpm, $10 \mathrm{~min}$ ), the supernatant was collected and split into two phases by adding chloroform and citrate buffer. The lipid extract was taken, dried under a $\mathrm{N}_{2}$ stream, and stored at $-20{ }^{\circ} \mathrm{C}$. The lipids were fractionated in a column (Varian, HF BOND ELUT LRC SI, $500 \mathrm{mg}$ ) into neutral-, glycol-, and phospholipids containing polar lipids. The latter were dried under a stream of $\mathrm{N}_{2}$ and saved for preparation into fatty acid methyl esters.

\subsubsection{Transesterification}

Methyl nonadecanoate and tridecanoate were added as internal standards before the lipids were transferred to fatty acid methyl esters by mild alkaline methanolysis, separated, and analyzed on a gas chromatograph (Agilent Technologies, 6890N Network GC System). The column used was $30 \mathrm{~m}$ ZB-5ms, with film thickness of $0.25 \mu \mathrm{m}$ (Zebron).

The fatty acid methyl esters were identified by retention time comparison using a standard bacterial acid methyl ester mix (Supelco, BAME 47080-U, FAME 47885-U).

Fatty acid nomenclature follows that described by Frostegård et al. (1993). The fatty acids chosen for our data analysis were 14:0,

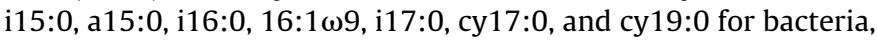
and $18: 3 \omega 6$ and $18: 2 \omega 6,9$ for fungi (Zelles, 1997).

\subsection{Soil fauna}

\subsubsection{Protozoa}

The number of culturable Protozoa was estimated using the most probable number (MPN) method by Rønn et al. (1995). Briefly, each well of a microtiter plate (Costar no. 3598) received 
$100 \mu \mathrm{l}$ of sterilized tryptic soy broth (TSB, Difco ${ }^{\circledR}$ ) solution $\left(0.1 \mathrm{~g} \mathrm{l}^{-1}\right)$. Five grams of fresh soil was mixed for $1 \mathrm{~min}$ in $100 \mathrm{ml}$ of TSB $\left(0.1 \mathrm{~g} \mathrm{l}^{-1}\right)$ with a kitchen blender, and a subsample $(50 \mu \mathrm{l})$ was taken and transferred to the first row of the microtiter plates. By mixing and transferring the subsamples from one rank to the next, a dilution series was prepared. The plates were stored in a climate cabinet at $15^{\circ} \mathrm{C}$ and checked for protozoa after 7 and 21 days. Calculation of the MPN of Protozoa was performed according to Briones and Reichardt (1999).

\subsubsection{Nematodes}

Fifteen grams of fresh soil was used for nematode extraction using the wet funnel method by Sohlenius (1979). The extracted nematodes were fixed in $4 \%$ formalin, and counted, and the feeding groups of 100 individuals were determined according to Bongers (1988) and Yeates et al. (1993). At the third sampling, plant parasitic nematodes (PPNs) were also extracted from roots. The roots were then gently washed, cut into $1-\mathrm{cm}$ pieces, and the nematodes were extracted using the same method as described above.

\subsubsection{Collembola}

Approximately $100 \mathrm{~g}$ of fresh soil was taken for the extraction of soil microarthropods using a slightly modified high-gradient extractor (MacFadyen, 1961) for 4 days. The animals were collected in ethanol, and Collembola were counted under a binocular microscope.

\subsubsection{Enchytraeid worms}

Enchytraeid worms were extracted from approximately $30 \mathrm{~g}$ of fresh soil using the wet funnel method by O'Connor, 1967. After extraction, the worms were counted within 2 days. At the second and third samplings, the animals were separated into size classes to estimate their biomass according to Abrahamsen (1973).

\subsubsection{Abiotic analyses}

Lysimeter water samples were taken right after (sampling 1) or before (samplings 2 and 3 ) the actual soil sampling by gently irrigating each of the mesocosm sectors with $1 \mathrm{l}$ of tap water. Ten minutes after irrigation, the water that percolated through the soil was sucked out of the lysimeter using a syringe, and $100 \mathrm{ml}$ of the leachate was collected in plastic bottles and frozen $\left(-20^{\circ} \mathrm{C}\right)$ until analysis for phosphate, nitrate, and ammonium using a QuikChem 8000 (Lachat Instruments, Milwaukee, WI, USA). Soil $\mathrm{pH}$ at samplings 2 and 3 was measured in a $0.01 \mathrm{M}$ $\mathrm{CaCl}_{2}$ solution.

\subsubsection{Statistical analyses}

The experiment was designed so that the soil biota can freely choose their desired plant-soil milieu in the mesocosms. Consequently, the different plant treatments were not arranged independently of one another within a mesocosm. Therefore the nonparametric Friedman test was applied for testing the general plant effect on the response variables. Due to the lack of a nonparametric model for repeated measurements, the plant effects on the variables were analyzed separately for each sampling time. The Wilcoxon ranking test was used for pairwise comparisons of the plant treatments (Lozán and Kausch, 2004). After testing the normality of the data using the Kolmogorov-Smirnov-test, Pearson correlations were performed to explore relationships between the variables. The statistical package SPSS 15.0 for Windows (SPSS, 2006) was used for all statistical analyses.

\section{Results}

\subsection{Soil microbes}

In general, the number of soil biota groups responding significantly to plant treatment increased with time (Table 1). Microbial activity (Fig. 1) and biomass (data not shown), which were estimated using the SIR method, were already significantly affected at the first sampling, and the differences became more pronounced over time (Table 1 ). Herein the microbial activity and biomass were enhanced beneath Lotus. The plant-free control soil always showed the lowest microbial biomass, and at the two first samplings also the lowest microbial activity. Microbial biomass followed the same pattern as microbial activity for the three sampling times (data not shown).

The fungal-to-bacterial biomass ratio (estimated by the PLFA method) was significantly affected by the plant treatments at the third sampling only (Table 1, Fig. 2), when a higher fungal-tobacterial ratio was found beneath Calluna than beneath the other treatments. By the end of the third growing season, fruiting bodies of the ectomycorrhizal fungus Hebeloma sp. were found in the sectors growing Picea in 5 of the 8 replicate mesocosms.

\subsection{Soil fauna}

Plant treatment had a significant but inconsistent effect on the abundance of Protozoa at the second and third samplings (Table 1).

The total number of nematodes was significantly higher beneath Lotus than beneath the other treatments from the second sampling onwards (Fig. 3). Plant treatment did not affect the

Table 1

Influence of plant treatment on soil variables at the three samplings $(P$-values derived from the Friedman test, ns $=$ not significant, nd $=$ not determined $)$.

\begin{tabular}{|c|c|c|c|}
\hline & Sampling 1 & Sampling 2 & Sampling 3 \\
\hline Basal respiration $\left(\mu \mathrm{g} \mathrm{CO}_{2} \mathrm{~g}_{\text {soil }} \mathrm{dm}^{-1}\right)$ & 0.02 & $<0.001$ & 0.004 \\
\hline $\operatorname{SIR}\left(\mu \mathrm{gCO}_{2}\right.$ g soil dm$\left.^{-1}\right)$ & 0.03 & 0.004 & 0.001 \\
\hline fungi:bacteria ( $\mu$ g g soil $\mathrm{dm}^{-1}$ ) & ns & ns & 0.016 \\
\hline MPN Protozoa/g soil dm & ns & 0.048 & 0.036 \\
\hline Nematodes ind./g soil dm & ns & 0.023 & 0.009 \\
\hline Bacterial feeding nematodes ind./g soil dm & ns & ns & ns \\
\hline Hyphal feeding nematodes ind./g soil dm & ns & ns & 0.023 \\
\hline Fungal:bacterial feeders ratio ind./g soil dm & ns & nd & ns \\
\hline Sucking predators ind./g soil dm & ns & ns & ns \\
\hline Ingesting predators ind./g soil dm & ns & ns & ns \\
\hline Total predators ind./g soil dm & ns & ns & 0.032 \\
\hline Omnivorous nematodes ind./g soil dm & ns & ns & ns \\
\hline Plant parasitic nematodes ind./g soil dm & ns & ns & 0.001 \\
\hline Plant parasitic nematodes ind./g root dm & nd & nd & 0.002 \\
\hline Enchytraeid ind./g soil dm & ns & ns & 0.001 \\
\hline Enchytraeid biomass ( $\mu \mathrm{g} / \mathrm{g}$ soil $\mathrm{dm}$ ) & nd & ns & 0.004 \\
\hline Collembola ind./g soil dm & nd & 0.031 & ns \\
\hline
\end{tabular}




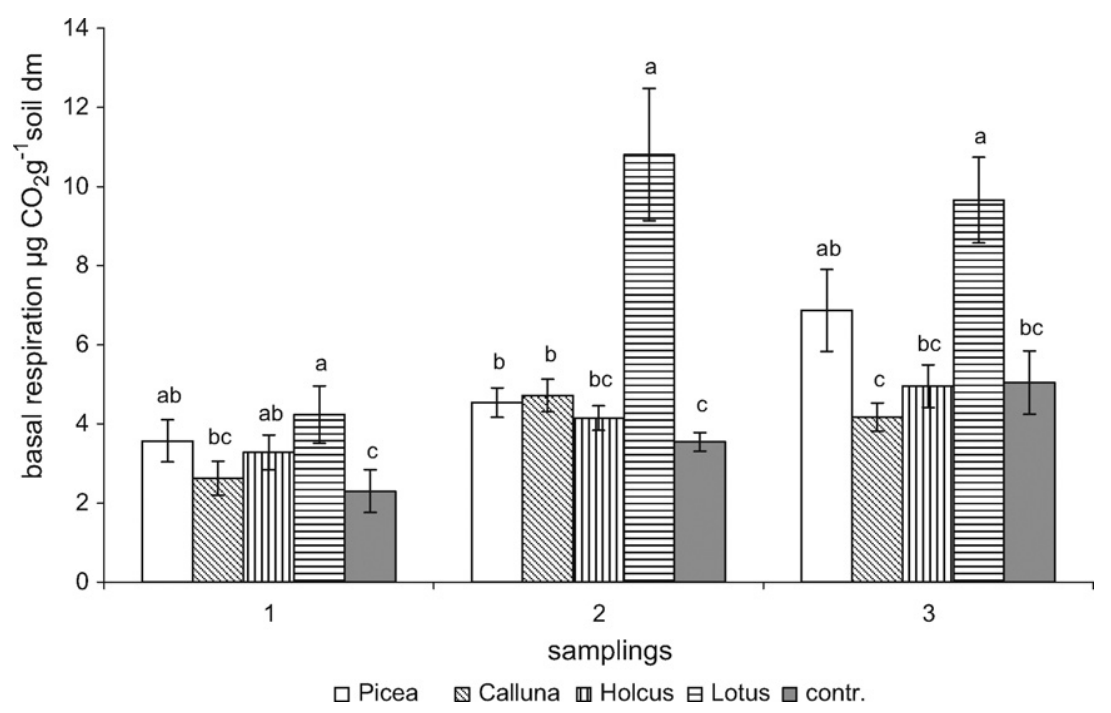

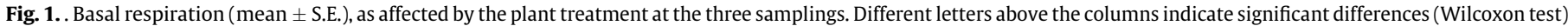
between the treatments within a sampling. Control = plant-free soil.

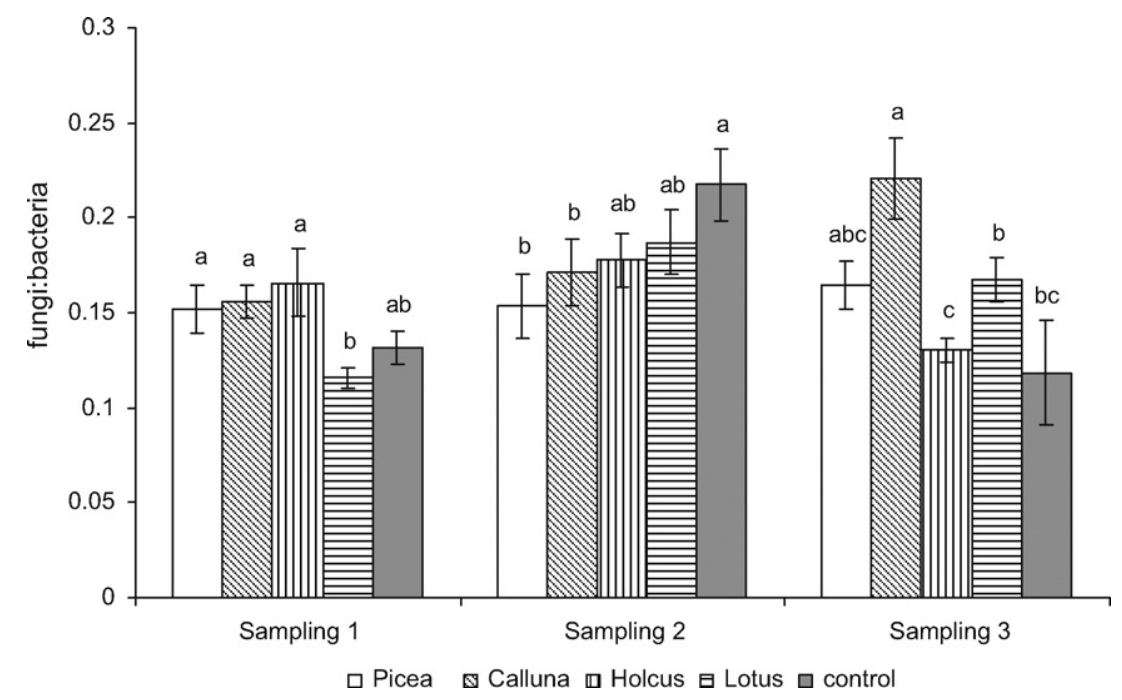

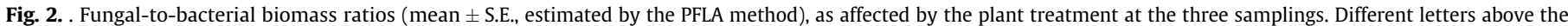
columns indicate significant differences (Wilcoxon test) between the treatments within a sampling. Control = plant-free control soil.

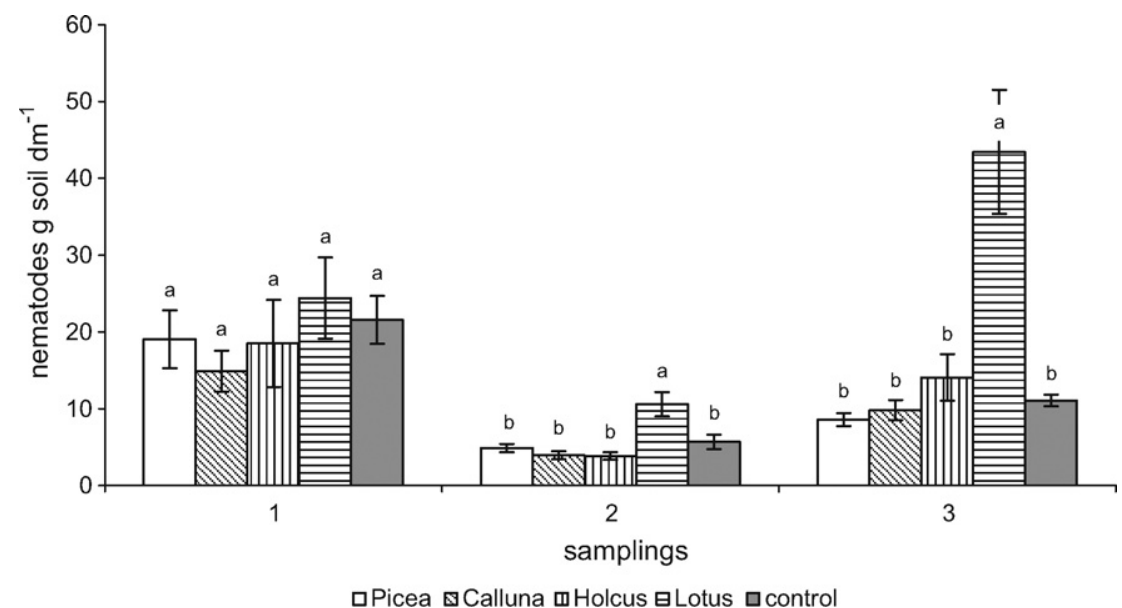

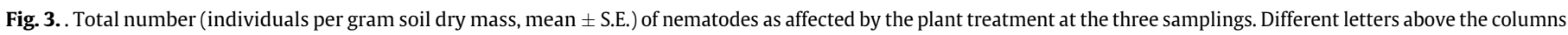
indicate significant differences (Wilcoxon test) between the treatments within a sampling. Control = plant-free control soil. 


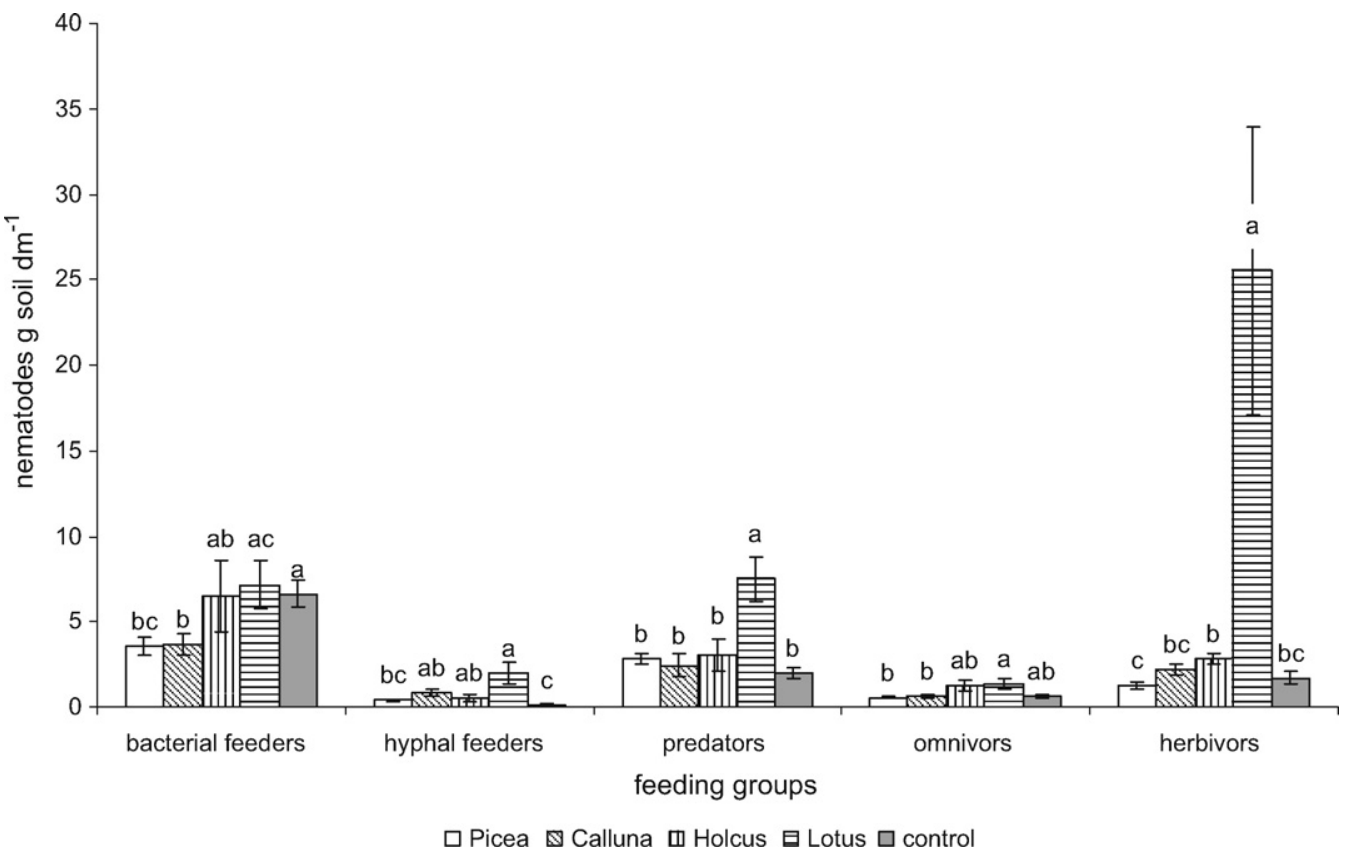

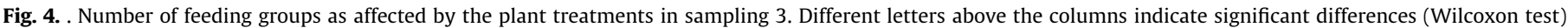
between feeding groups in different plant treatments. Control = plant-free control soil.

composition of the soil-inhabiting nematode feeding groups during the first two samplings. However, at the final sampling the numbers of fungal feeders (lowest numbers in plant-free control soils), predators (most abundant in Lotus soils), and plant parasites (mostly Pratylenchus and Paratylenchus, most abundant in Lotus soils) were significantly affected by the plant treatment (Fig. 4). Although the Friedman test did not show significant treatment effects on the abundance of bacterial-feeding nematodes, pair wise comparisons (Wilcoxon test) indicated that the number of bacterial feeders was lower in the Picea and Calluna soils than in the other treatments at the final sampling (Fig. 4). Ratios of fungal to bacterial feeding nematodes were not significantly affected by the plant treatment in samplings 1 and 3 (Table 1), neither were they correlated to fungal-to-bacterial ratios of PLFA. Pairwise comparisons of fungal-to-bacterial feeding nematode ratios showed for the final sampling distinct differences (Fig. 5). In

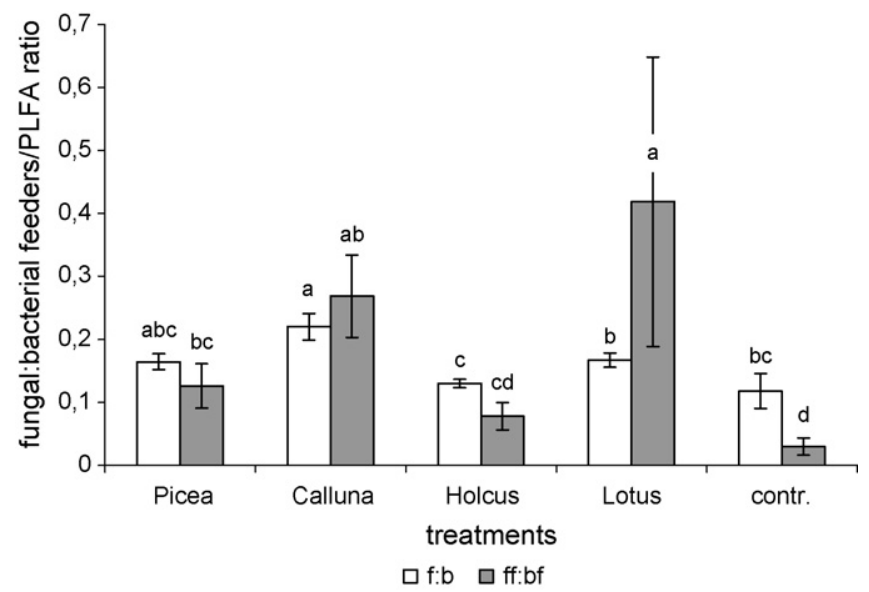

Fig. 5. . Ratios of fungal to bacterial feeding nematodes and fungal to bacterial biomass of PLFA (mean \pm S.E.) as affected by the plant treatments at sampling 3 . Different letters above the columns indicate significant differences (Wilcoxon test) between the treatments. Control = plant-free control soil. sampling 2 the ratios could not be determined, due to the high number of zero values in the number of fungal feeding nematodes. Plant parasitic nematodes (mostly Pratylenchus and Paratylenchus) extracted from roots in the final sampling were significantly more abundant in Holcus and Lotus roots than in Picea or Calluna roots (Fig. 6).

Plant treatment had little influence on the number and biomass of enchytraeid worms at the first two samplings. At the final sampling, Holcus and Lotus soils harbored significantly more worms of higher biomass (on average 0.6 individuals $\mathrm{g}^{-1}$ dry soil) than the other plant treatments (varying between 0.22 and $0.39 \mathrm{~g}^{-1}$ dry soil) (Table 1 ).

Collembolans were significantly affected by the plant treatment, but only at the second sampling (Table 1), when more animals were found beneath Holcus and Lotus than beneath the other plant treatments (data not shown).

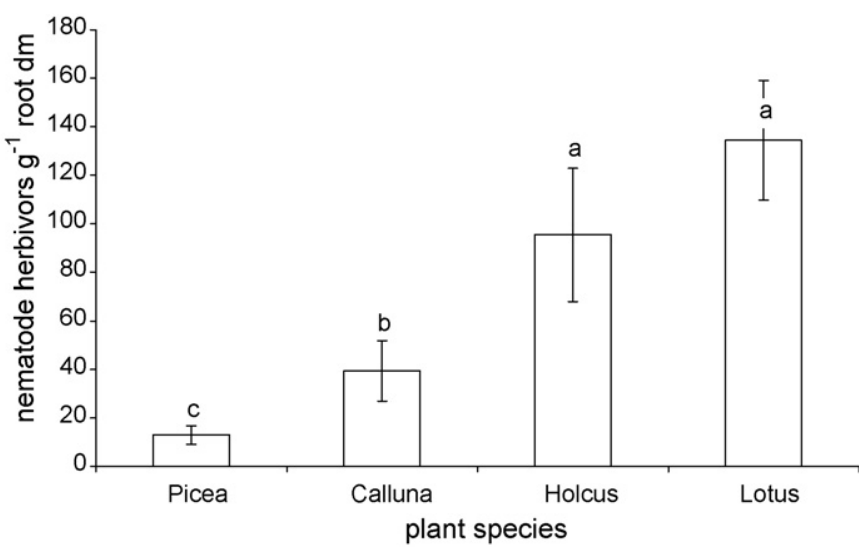

Fig. 6. . Number of plant parasitic nematodes per gram root dry mass at the final sampling (means \pm S.E.), as affected by the plant treatment at the three samplings. Different letters above the columns indicate significant differences (Wilcoxon test) between the treatments. Control = plant-free control soil. 
Table 2

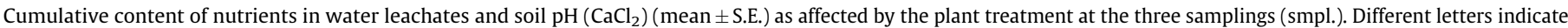
significant differences (Wilcoxon test) between the treatments within a sampling. Contr. = plant-free soil.

\begin{tabular}{|c|c|c|c|c|c|c|c|}
\hline & Smpl. & Picea & Calluna & Holcus & Lotus & Contr. & Friedman test $(P)$ \\
\hline \multirow[t]{3}{*}{$\mathrm{NO}_{3}{ }^{-}-\mathrm{N}(\mu \mathrm{g} / \mathrm{l})$} & 1 & $174 \pm 11 c$ & $376 \pm 51 b$ & $143 \pm 4 c$ & $718 \pm 62 a$ & $231 \pm 39 b c$ & 0.001 \\
\hline & 2 & $1029 \pm 108 b$ & $1710 \pm 292 a$ & $447 \pm 21 c$ & $1718 \pm 81 \mathrm{a}$ & $1868 \pm 295 a$ & $<0.001$ \\
\hline & 3 & $1590 \pm 114 b$ & $2472 \pm 487 a b$ & $2534 \pm 1038 a b$ & $2842 \pm 295 a$ & $3846 \pm 632 a$ & 0.014 \\
\hline \multirow[t]{2}{*}{$\mathrm{NH}_{4}{ }^{+}-\mathrm{N}(\mu \mathrm{g} / \mathrm{l})$} & 2 & $61 \pm 5 b$ & $70 \pm 6 b$ & $89 \pm 12 a b$ & $66 \pm 27 a b$ & $104 \pm 22 a$ & 0.069 \\
\hline & 3 & $117 \pm 7 b$ & $125 \pm 7 b$ & $178 \pm 9 a$ & $139 \pm 26 a b$ & $185 \pm 20 a$ & 0.016 \\
\hline \multirow[t]{3}{*}{$\mathrm{PO}_{4}{ }^{3-}(\mu \mathrm{g} / \mathrm{l})$} & 1 & $1818 \pm 236 a b$ & $1642 \pm 164 b$ & $2485 \pm 155 a$ & $1700 \pm 107 b$ & $1938 \pm 155 b$ & 0.069 \\
\hline & 2 & $3974 \pm 521 b$ & $4556 \pm 431 b$ & $6221 \pm 555 a$ & $3932 \pm 252 b$ & $4965 \pm 560 a b$ & 0.011 \\
\hline & 3 & $5200 \pm 681 c$ & $6314 \pm 560 b c$ & $9641 \pm 937 a$ & $5329 \pm 269 b c$ & $6961 \pm 743 b$ & 0.003 \\
\hline \multirow[t]{2}{*}{$\mathrm{pH}\left(\mathrm{CaCl}_{2}\right)$} & 2 & $5.74 \pm 0.07 \mathrm{ab}$ & $5.79 \pm 0.04 a$ & $5.59 \pm 0.05 b$ & $5.30 \pm 0.1 c$ & $5.53 \pm 0.05 b$ & 0.002 \\
\hline & 3 & $5.46 \pm 0.05 b$ & $5.45 \pm 0.07 b$ & $5.71 \pm 0.06 a$ & $5.42 \pm 0.12 \mathrm{ab}$ & $5.36 \pm 0.09 b$ & 0.039 \\
\hline
\end{tabular}

\subsection{Abiotic parameters}

The cumulative concentration of nitrate in water leachates was significantly affected by the plant treatments in all samplings (Table 2). At the two first samplings, leaching of nitrate was reduced in the Holcus soils. At the third sampling, leaching of nitrate from Picea soils was significantly reduced compared with Lotus and the plant-free control (Table 2).

Due to technical reasons cumulative data of ammonium concentration in water leachates are available for samplings 2 and 3 only (Table 2 ). Herein plant treatment significantly affected ammonium leaching in sampling 3 (Table 2).

Statistical analyses for cumulative concentrations of phosphate in water leachates showed significant differences in the latter two samplings (Table 2), though from the beginning more phosphate leached out from Holcus soils.

Plant treatment did not have a consistent impact on soil $\mathrm{pH}$. At the second sampling, pH was significantly lower in Lotus and significantly higher in Picea and Calluna soils than in the unplanted soil, while at the final sampling $\mathrm{pH}$ was significantly higher in Holcus soils in comparison to the unplanted soil and Picea and Calluna soils (Table 2).

\section{Discussion}

Our results confirmed previous findings suggesting that plant species can modify the soil decomposer community structure, but contrary to our prediction this did not give rise to the establishment of distinct energy channels beneath the plants. However, even though the microbial biomass was dominated by bacteria in all treatments at all samplings, there was a significant increase in fungal biomass relative to bacterial biomass under Calluna in comparison to the other treatments at the end of the study. This indicates that, within a period of less than 2 years, this shrub has the potential to modify the soil in the expected manner. Whether the Calluna-derived effects on soil microbes are due to Calluna litter or the presence of ericoid mycorrhizal fungi in Calluna roots remains unclear. If the presence of mycorrhizal fungi of different types (ericoid, ectomycorrhizal) would pose a significant effect on the build-up of a clearly separated fungal-based energy channel, it remains open why the Picea plants with a seemingly welldeveloped ectomycorrhizal rhizosphere did not result in fungal dominance in the soils. The long agricultural legacy of the experimental soil may still favor bacteria over fungi, since $85 \%$ of the relative microbial biomass in the plant-free control soils was composed of bacteria. It cannot be ruled out that the low fungal biomass in our study soils may be due to an underestimation of the fungal marker linoleic acid $(18: 2 \omega 6,9)$ in the PLFA-analysis. In addition, this fungal biomarker detects only saprophytic and ectomycorrhizal fungi, but not arbuscular mycorrhizal fungi, which were most probably also present. Joergensen and Wichern (2008) and de Vries et al. (2009) recently showed that fungal biomass is often underestimated when compared with ergosterol analysis or microscopic measurements in the soil.

As soil microbes generally did not respond to plant species identity as anticipated, it is hardly surprising that their consumers failed to respond significantly to the plant treatments as hypothesized. For example, although bacterial biomass was clearly enhanced beneath Lotus, the number of microbial-feeding microfauna (Protozoa, nematodes) did not follow this pattern. Furthermore, and in contrast to our assumption, Collembola numbers in sampling 2 were highest beneath Holcus and Lotus, which are in general not regarded to support resources for these fungal feeders (Maraun et al., 2003). Recently Endlweber and Scheu (2007) suggested that high numbers of Collembola under grass species indicate that these animals are not obligatory fungal feeders, but rather graze directly on roots or root exudates. This is supported by the findings of our study-at least during the early stages of the experiment. However, the lack of consistent evidence on the existence of distinct detritus energy channels in our experiment leads us to refute our first and second hypotheses.

It is likely that the short-term manipulation of the plant-soil system was not sufficient to stimulate the development of distinct bacterial- and fungal-dominating systems. As reported by DoblasMiranda et al. (2008), the development of a microbiologically stable soil is a long-term, multifactorial successional process, where the build-up phase can last up to 5000 years. In line with this, Coleman et al. (1983) pointed out that the formation of a fungal-dominating food web requires undisturbed conditions, preferably a late successional stage of the ecosystem. Holtkamp et al. (2008) found no distinct cascading effects on organisms of different trophic levels within an energy channel, even though their study sites were up to 22 years old. However, Habekost et al. (2008) showed in a field experiment that the effects of grassland plants on microbes in former arable land were detectable already 4 years after abandonment. Similarly, van der Wal et al. (2006) found that fungal biomass in former arable land increased already during the first 2 years after abandonment, after which either a very slow increase or a stabilization phase of decades took place. These findings, as well as our results, suggest that the development of a fungal-dominating soil is a long-term ecosystem-level process in which various factors are involved. Furthermore, the same plant species can behave differently depending on the soil characteristics, as for example shown by Innes et al. (2004) for H. lanatus in soils of varying fertility.

Although we concentrated on exploring the existence of the two different detritus channels, we found a clear evidence for the presence of a root channel under Lotus towards the end of the study. This channel was characterized by high numbers of plant parasitic and predatory nematodes. Also Saj et al. (2007) and Wurst 
et al. (2009), applying the same soil as in the present experiment, found high numbers of plant parasitic, but not predatory nematodes in $L$. corniculatus soils. Saj et al. (2007) and Wurst et al. (2009) suggested that nutrient $(\mathrm{N})$ leaking from Lotus roots due to nematode feeding results in stimulated growth of bacteria and their grazers, Protozoa- and bacterial-feeding nematodes. This in turn can lead to an increased nutrient supply for the plant itself as suggested by Bardgett et al. (1999a,b). Whether the root channel had a role to play in affecting the performance of Lotus in our experiment remains open.

We also hypothesized that less nitrogen and phosphorus will be retained in the Holcus, Lotus, and unplanted control soils than in the Calluna and Picea soils, because fungi and organisms within the fungal energy channel have a spatial and temporal advantage over the bacterial one to keep nutrients in the system. This is due to the large surface area of the fungi itself, its ability to transfer and store nutrients within the hyphal network, and the longer generation times of the faunal members of the entire energy channel (Coleman et al., 1983). This prediction was partly supported when the cumulative amounts of nutrients are concerned. At the end of the study less nitrate and ammonium leached from Picea soils than from the unplanted control soils and more phosphate leached from Holcus soils than from the others. This gives support to the notion that liberation of nutrients from soil organic matter is controlled by an array of parameters, where plant species identity plays a decisive role (Swift et al., 1979). For example soil pH (Scheffer and Schachtschabel, 2002) and high amounts of phenolic compounds in plant litter (Ehrenfeld et al., 2005) can control nutrient dynamics and affect $\mathrm{N}$ mineralization. At the final sampling, soil $\mathrm{pH}$ decreased beneath Calluna and Picea compared to the first sampling, but beneath Holcus it was significantly increased in comparison to the unplanted soil. Conifers, especially spruce, reduce soil pH (Nykvist, 1963), and Calluna litter is known to contain high amounts of phenolic compounds (Bardgett, 2005) with an acidifying effect on soils. Whether the significantly lower soil pH in Calluna and Picea soils than in other plant treatments is due to litter effects or root exudation effects requires further investigation.

In summary, this study provides evidence that a single plant species can, in a relatively short period, modify the soil decomposer community composition, but not necessarily in the way predicted by the soil detritus energy/nutrient channel theory by Moore and Hunt (1988). Nevertheless we found a clearly separated root channel under the legume $L$. corniculatus, which supports findings that this legume is an important intermediator of plants and soil organisms with respect to nutrient cycling and succession (Bardgett, 2005). We suggest that development of a fungal-based pathway that reaches the consumer level of the soil food web is unlikely to take place unless the entire plant community is made up of slow-growing plants producing recalcitrant litter. Our results corroborate findings that plants take influence on the soil in multifactorial pathways (Wardle, 2002), in which the spatial and temporal (succession) scales should not be overlooked (Wardle et al., 2004; Bardgett, 2005).

\section{Acknowledgments}

This study is part of the EU-funded project "Biotic interactions in the rhizosphere as structuring forces for plant communities" (BIORHIZ). We thank M. Suontaus for performing the PLFA analyses and three anonymous reviewers for helpful comments.

\section{References}

Abrahamsen, G., 1973. Biomass and body-surface area of populations of enchytraeidae and lumbricidae (Oligochaeta) in Norwegian coniferous forest soils. Pedobiologia 13, 28-39.
Bais, H.P., Weir, T.L., Perry, L.G., Gilroy, S., Vivanco, J.M., 2006. The role of root exudates in rhizosphere interactions with plants and other organisms. Annual Review of Plant Biology 57, 233-266.

Bardgett, R.D., Mawdsley, J.L., Edwards, S., Hobbs, P.J., Rodwell, J.S., Davies, W.J., 1999a. Plant species and nitrogen effects on soil biological properties of temperate upland grasslands. Functional Ecology 13, 650-660.

Bardgett, R.D., McAlister, E., 1999. The measurement of soil fungal:bacterial ratios as an indicator of ecosystem self-regulation in temperate meadow grasslands. Biology and Fertility of Soils 29, 282-290.

Bardgett, R.D., Shine, A., 1999. Linkages between plant litter diversity, soil microbial biomass and ecosystem function in temperate grasslands. Soil Biology and Biochemistry 31, 317-321.

Bardgett, R.D., Cook, R., Yeates, G.W., Denton, C.S., 1999b. The influence of nematodes in below-ground processes in grasslands ecosystems. Plant and Soil 212, 23-33.

Bardgett, R.D., 2005. The Biology of Soil-A Community and Ecosystem Approach. Oxford University Press, USA, Oxford.

Beck, T., Öhlinger, R., Baumgarten, A., 1995. Substrate induced respiration. In: Schinner, F., Öhlinger, R., Kandeler, E., Margesin, R. (Eds.), Methods in Soil Biology. Springer, Berlin, pp. 64-68

Bever, J.D., 2003. Soil community feedback and the coexistence of competitors: conceptual frameworks and empirical tests. New Phytologist 157, 465-473.

Bongers, T., 1988. De Nematoden van Nederland. Stichting Uitgeverij Koninklijke Nederlandse Natuurhistorische Vereninging, Utrecht.

Bonkowski, M., Cheng, W., Griffiths, B.S., Alphei, J., Scheu, S., 2000. Microbial-faunal interactions in the rhizosphere and effects on plant growth. European Journal of Soil Biology 36, 135-147.

Bonkowski, M., Jentschke, G., Scheu, S., 2001. Contrasting effects of microbial partners in the rhizosphere: interactions between Norway Spruce seedlings (Picea abies Karst.), mycorrhiza (Paxillus involutus (Batsch) Fr.) and naked amoebae (protozoa). Applied Soil Ecology 18, 193-204.

Bradley, R.L., Fyles, J.W., 1995. Growth of paper birch (Betula papyrifera) seedlings increases soil available $C$ and microbial acquisition of soil-nutrients. Soil Biology and Biochemistry 27 (12), 1565-1571.

Briones, A.M., Reichardt, W., 1999. Estimating microbial population counts by 'most probable number' using Microsoft Excel ${ }^{\mathbb{R}}$. Journal of Microbiological Methods 35, 157-161.

Coleman, D.C., Reíd, C.P.P., Cole, C.V., 1983. Biological strategies of nutrients cycling in soil systems. In: Macfayden, A., Ford, E.D. (Eds.), Advances in Ecological Research. Academic Press, London, pp. 1-44.

de Boer, W., Folman, L.B., Summerbell, R.C., Boddy, L., 2005. Living in a fungal world: impact of fungi on soil bacterial niche development. FEMS Microbiology Reviews 29, 795-811.

de Deyn, G.B., Raaijmakers, J.M., van Ruijven, J., Berendse, F., van der Putten, W.H. 2004. Plant species identity and diversity effects on different trophic levels of nematodes in the soil food web. Oikos 106, 576-586.

de Vries, F.T., Hoffland, E., van Eekeren, N., Brussaard, L., Bloem, J., 2006. Fungal/ bacterial ratios in grasslands with contrasting nitrogen management. Soil Biology and Biochemistry 38, 2092-2103.

de Vries, F.T., Bååth, E., Kuyper, T.W., Bloem, J., 2009. High turnover of fungal hyphae in incubation experiments. FEMS Microbial Ecology 67, 389-396.

Doblas-Miranda, E., Wardle, D.A., Peltzer, D.A., Yeates, G.W., 2008. Changes in the community structure and diversity of soil invertebrates across the Franz Josef Glacier chronosequence. Soil Biology and Biochemistry 40, 1069-1081.

Ehrenfeld, J.G., Ravit, B., Elgersma, K., 2005. Feedback in the plant-soil-system. Annual Review of Environment and Resources 30, 75-115.

Endlweber, K., Scheu, S., 2007. Interactions between mycorrhizal fungi and Collembola: effects on root structure of competing plant species. Biology and Fertility of Soils 43 741-749.

Frostegård, A., Tunlid, A., Bååt, E., 1991. Microbial biomass measured as total lipid phosphate in soils of different organic content. Journal of Microbiological Methods 14, 151-163.

Frostegård, Å., Tunlid, A., Bååt, E., 1993. Phospholipid fatty acid composition, biomass, and activity of microbial communities from two soil types experimentally exposed to different heavy metals. Applied and Environmental Microbiology 59, 3605-3617.

Genney, D.R., Alexander, I.J., Hartley, S.E., 2000. Exclusion of grass roots from soil organic layers by Calluna: the role of ericoid mycorrhizas. Journal of Experimental Botany 51 (347), 1117-1125.

Gordon, H., Haygarth, P.M., Bardgett, R.D., 2008. Drying and rewetting effects on soil microbial community composition and nutrient leaching. Soil Biology and Biochemistry 40, 302-311.

Habekost, M., Eisenhauer, N., Scheu, S., Steinbeiss, S., Weigelt, A., Gleixner, G., 2008. Seasonal changes in the soil microbial community in a grassland plant diversity gradient four years after establishment. Soil Biology and Biochemistry 40, 2588-2595.

Hedlund, K., Santa Regina, I., van der Putten, W.H., Lepš, J., Díaz, T., Korthals, G.W., Lavorel, S., Brown, V.K., Gormsen, D., Mortimer, S.R., Rodriguez Barrueco, C., Roy, J., Smilauer, P., Smilauerovà, M., van Dijk, C., 2003. Plant species diversity, plant biomass and responses of the soil community on abandoned land across Europe: idiosyncracy or above-belowground time lags. Oikos 103, 45-58.

Holtkamp, R., Kardol, P., van der Wal, A., Dekker, S.C., van der Putten, W.H., de Ruiter P.C., 2008. Soil food web structure during ecosystem development after land abandonment. Applied Soil Ecology 39, 23-34

Hopkin, S.P., 1997. Biology of the Springtails. Oxford University Press, Oxford/New York/Tokyo (Insecta: Collembola). 
Ingestad, T.O., 1979. Mineral nutrient requirements of Pinus sylvestris and Picea abies seedlings. Physiologia Plantarum 45, 373-380.

Ingham, R.E., Trofymow, J.A., Ingham, E.R., Coleman, D.C., 1985. Interactions of bacteria, fungi, and their nematode grazers: effects on nutrient cycling and plant growth. Ecological Monographs 55 (1), 119-140.

Innes, L., Hobbs, P.J., Bardgett, R.D., 2004. The impacts of individual plant species on rhizosphere microbial communities in soils of different fertility. Biology and Fertility of Soils 40, 7-13.

Joergensen, R.G., Wichern, F., 2008. Quantitative assessment of the fungal contribution to microbial tissue in soil. Soil Biology and Biochemistry 40, 2977-2991.

Knapp, B.A., Podmirseg, S.M., Seeber, J., Meyer, E., Insam, H., 2009. Diet-related composition of the gut microbiota of Lumbricus rubellus as revealed by molecular fingerprinting technique and cloning. Soil Biology and Biochemistry 41, 2299-2307.

Lozán, L.J., Kausch, H., 2004. Angewandte Statistik für Naturwissenschaftler. Wissenschaftliche Auswertungen, Hamburg.

MacFadyen, A., 1961. Improved funnel-type extractors for soil arthropods. Journal of Animal Ecology 30, 171-184.

Maraun, M., Martens, H., Migge, S., Theenhaus, A., Scheu, S., 2003. Adding to 'the enigma of soil animal diversity': fungal feeders and saprophagous soil invertebrates prefer similar food substrates. European Journal of Soil Biology 39, 8595.

Moore, J.C., Hunt, H.W., 1988. Resource compartmentation and the stability of real ecosystems. Nature 333, 261-263.

Mulder, C.P.H., Jumpponen, A., Högberg, P., Huss-Danell, K., 2002. How plant diversity and legumes affect nitrogen dynamics in experimental grassland communities. Oecologia 133, 412-421.

Nykvist, N., 1963. Leaching and decomposition of water-soluble organic substances from different types of leaf and needle litter. Studia Forestalia Suecica $3,1-31$.

O'Connor, F.B., 1967. The Enchytraeidae. In: Burges, A., Raw, F. (Eds.), Soil Biology. Academic Press, London, pp. 213-217.

Olsson, P.A., Chalot, M., Bååth, E., Finlay, R.D., 1996. Ectomycorrhizal mycelia reduce bacterial activity in a sandy soil. FEMS Microbiology Ecology 21, 77-86.

Petersen, H., Luxton, M., 1982. A comparative analysis of soil fauna populations and their role in decomposition processes. Oikos 39 (3), 288-388.

Priha, O., Smolander, A., 1997. Microbial biomass and activity in soil and litter beneath Pinus sylvestris, Picea abies and Betula pendula at originally similar field afforestation sites. Biology and Fertility of Soils 24, 45-51.

Priha, O., Grayston, S.J., Hiukka, R., Pennanen, T., Smolander, A., 2001. Microbial community structure and characteristics of the organic matter in soils beneath Pinus sylvestris, Picea abies and Betula pendula at two forest sites. Biology and Fertility of Soils 33, 17-24.

Rønn, R., Ekelund, F., Christensen, S., 1995. Optimizing soil extract and broth media for MPN-enumeration of naked amoeba and heterotrophic flagellates in soil. Pedobiologia 39, 10-19.

Saj, S., Mikola, J., Ekelund, F., 2007. Root-induced decomposer growth and plant N uptake are not positively associated among a set of grassland species. Applied Soil Ecology 37, 215-222.

Scheffer, F., Schachtschabel, P., 2002. Lehrbuch der Bodenkunde. Spektrum Akademischer Verlag, Heidelberg Berlin.
Scheublin, T.R., Ridgway, K.P., Young, P.W., van der Heijden, M.G.A., 2004. Nonlegumes, legumes, and root nodules harbour different arbuscular fungal communities. Applied and Environmental Microbiology 70 (10), 6240-6246.

Sohlenius, B., 1979. A carbon budget for nematodes, rotifers and tardigrades in a Swedish coniferous forest soil. Holartic Ecology 2, 30-40.

SPSS, 2006. SPSS 15.0 for Windows. SPSS, Chicago, USA.

Swift, M.J., Heal, O.W., Anderson, J.M., 1979. Decomposition in terrestrial ecosystems. In: Anderson, D.J., Greig-Smith, P., Pitelka, Frank, A. (Eds.), Studies in Ecology, vol. 5. Blackwell Scientific Publications, Berkeley.

Timonen, S., Christensen, S., Ekelund, F., 2004. Distribution of protozoa in scots pine mycorrhizosphere. Soil Biology and Biochemistry 36, 1087-1093.

van der Heijden, M.G.A., Bardgett, R.D., van Straalen, N.M., 2008. The unseen majority: soil microbes as drivers of plant diversity and productivity in terrestrial ecosystems. Ecology Letters 11, 296-310.

van der Putten, W.H., Mortimer, S.R., Hedlund, K., van Dijk, C., Brown, V.K., Lepš, J., Rodriguez-Barrueco, C., Roy, J., Diaz Len, T.A., Gormsen, D., Korthals, G.W., Lavorel, S., Santa Regina, I., Smilauer, P., 2000. Plant species diversity as a driver of early succession in abandoned fields: a multi-site approach. Oecologia 124, 91-99.

van der Wal, A., van Veen, J.A., Smant, W., Boschker, H.T.S., Bloem, J., Kardol, P., van der Putten, W.H., De Boer, W., 2006. Fungal biomass development in a chronosequence of land abandonment. Soil Biology and Biochemistry 38, 51-60.

Wardle, D.A., Nicholson, K.S., 1996. Synergistic effects of grassland plant species on soil microbial biomass and activity: implications for ecosystem-level effects of enriched plant diversity. Functional Ecology 10, 410-416.

Wardle, D.A., 2002. Communities and Ecosystems-Linking the Above and Belowground Components. Princeton University Press, Princeton/Oxford.

Wardle, D.A., Yeates, G.W., Williamson, W.W., Bonner, K.I., 2003. The response of a three trophic level soil food web to the identity and diversity of plant species and functional groups. Oikos 102, 45-56.

Wardle, D.A., Bardgett, R.D., Klironomos, J.N., Setälä, H., van der Putten, W.H., Wall, D.H., 2004. Ecological linkages between aboveground and belowground biota. Science 304, 1629-1633.

Wardle, D.A., 2005. How plant communities influence decomposer communities. In: Bardgett, R.D., Usher, M.B., Hopkins, D.W. (Eds.), Biological Diversity and Function in Soils. Cambridge University Press, Cambridge, pp. 119-138.

Wardle, D.A., Yeates, G.W., Barker, G.M., Bonner, K.I., 2006. The influence of plant litter diversity on decomposer abundance and diversity. Soil Biology and Biochemistry 38 (5), 1052-1062.

West, H.M., 1996. Influence of arbuscular mycorrhizal infection on competition between Holcus lanatus and Dactylis glomerata. Journal of Ecology 84 (3), 429438.

Wurst, S., van Beersum, S., Wagenaar, R., Bakx-Schotman, T., Drogo, B., Janzik, I., Lanou, A., van der Putten, W.H., 2009. Plant defence against nematodes is not mediated by changes in the soil microbial community. Functional Ecology 23, 488-495.

Yeates, G.W., Bongers, T., de Goede, R.G.M., Freckmann, D.W., Georgieva, S.S., 1993 Feeding habits in soil nematode families and genera-an outline for soil ecologists. Journal of Nematology 25, 315-331.

Zelles, L., 1997. Phospholipid fatty acid profiles in selected members of soil microbial communities. Chemosphere 35 (1/2), 275-294. 